\title{
KEBIJAKAN RENCANA PEMBANGUNAN DESA SEBAGAI USAHA KESEJAHTERAAN SOSIAL MASYARAKAT DI DESA CIDOKOM
}

\author{
Enung Khoeriyah \\ Pendamping PKH kabupaten Ciamis \\ Email: khoeriyahsoeprdja17@gmail.com
}

Received: 03th April 2018; Revised: 13th July 2018; Accepted: 15th December 2018

\begin{abstract}
Village management is a crucial as the government closest unit to the community. So it needs a clear planning and arrangement to realize the welfare of the local community. A transparentplanning involving citizens through the Village Mid-Term Development Plan (RPJM Desa) and the Village Government Work Plan (RKP Desa). Citizens' engagement will produce results like meeting the needs of clothing, food and shelter, as well as to have an easy access to various services and other social activities. But creating a prosperous village community is uneasy; a government policy should be in place to regulate the welfare efforts, one of which is through a development policy. This research uses a descriptive qualitative approach. Data collection is performed through observation, interviews and documentationstudy. The findings show that the village development planning policy carried out based on the stages adjusted to the policy promulgated by the central government through Village Law Number 6 of 2014. Furthermore, it contains the elaboration of the stages of village development planning adjusted to the priority development policies. It is through this policy priority that Cidokom Village conducts a development program to improve the welfare of the village community.
\end{abstract}

Keywords: Village, Policy, Development Plan, Community Welfare.

Abstrak. Pengelolaan desa menjadi penting, sebab unit pemerintahan tersebut paling dekat dengan masyarakat. Sehingga perlu perencanaan dan penataan yang jelas untuk mewujudkan kesajahteraan masyarakat setempat. Perencanaan yang transparan dan juga melibatkan warga dapat melalui Rencana Pembangunan Jangka Menengah Desa (RPJMDesa) dan Rencana Kerja Pemerintah Desa (RKPDesa). Pelibatan Warga akan membuahkan hasil terhadap terpenuhinya kebutuhann sandang, pangan, dan papan., serta untuk memiliki akses yang mudah pada berbagai layanan dan kegiatan sosial lainnya. Namun mewujudkan masyarakat desa yang sejahtera tidaklah mudah, perlu adanya kebijakan pemerintah yang mengatur langsung usaha kesejahteraan, salah satunya melalui pembangunan. Penelitian ini mengunakan pendekatan kualitatif deskriprif. Tujuannya untuk memudahkan peneliti dalam menjelaskan bagaiman hasil temuan diperoleh di lapangan. Adapun metodenya melalui observasi, wawancara dan juga studi dokumentasi. Hasil penelitian menunjukan bahwa kebijakan perencanaan pembangunan desa dilakukan berdasarkan tahapan yang disesuaikan dengan kebijakanyangtelah dibuat olehpemerintahpusat melalui undang- undang desa nomor 6 tahun 2014. Selanjutnya berisi penjabaran tahapan perencanaan pembangunan desa yang disesuaikan dengan kebijakan prioritas pembangunan. Melalui prioritas kebijakan inilah Cidokom melakukan program pembangunan untuk meningkatkan kesejahteraan masyarakat desa.

Kata Kunci: Desa, Kebijakan, Rencana Pembangunan, Kesejahteraan Masyarakat. 


\section{Kebijakan Rencana Pembangunan Desa sebagai Usaha \\ Kesejahteraan Sosial Masyarakat di Desa Cidokom}

Enung Khoeriyah

\section{Pendahuluan}

Unit pemerintahan yang paling dekat dan menyentuh langsung kehidupan masyarakat yakni desa. Segala urusan baik yang berkaitan dengan administrasi dan bahkan untuk memajukan kesejahteraan seyogianya melalu pemerintahan paling tersebut. Sehingga perlu sekiranya memberikan perhatian khusus terhadap perkembangannya. Secara sederhana desa terdiri dari dua krakteristik, yani desa geneologis dan desa pada umumnya. Ciri desa yang disebutkan pertama yakni ikatan yang terjalin karena ikatan darah dan turun temurun, biasanya dipimpin oleh ketua adat. Pimpinan desa harus tunduk kepada peratura adat yang ada, apabila menyimpang dari peraturan adat maka kepemimpinannya tidak akan diakui masyarakat, (Raharjo, 2010). Desa tipe kedua tidak terlalu memperhatikan ikatan darah, melainkan berlandaskan pada kepentingan bersama, dan dipimpin oleh kepala desa yang dipilih oleh masyarkat, bukan karena keturunan atau ditetapkan berdasarkan hukum adat.

Desa Cidokom termasuk dalam desa tipe kedua, yakni dengan dipimpin oleh kepala desa. Desa Cidokom (http:// kecamatangunungsindur.bogorkab.go.id, 2018), adalah salah satu desa yang berada di wilayah Kecamatan Gunungsindur Kabupaten Bogor Provinsi Jawa Barat yang sudah terbentuk sejak tahun1950, berada pada ketinggian $170 \mathrm{~m}$ DPL, dengan luas wilaya $300 \mathrm{Ha}$.

Masalah utama desa Cidokom yakni berkaitan dengan belum meratanya pembangunan desa terutama akses jalan desa yang merupakan akses utama bagi masyarakat untuk melakukan mobilitas sosial dan ekonomi. Jalan desa Cidokom masih terbuat dari bebatuan kapur yang memang banyak terdapat di Desa Cidokom, hal ini membuat akses jalan sulit untuk dilalui untuk berjalan kaki ataupun menggunakan kendaraan terutama jika sedang musim hujan. Hal ini terlihat dari kebijakan perencanaan pembangunan berdasarkan RPJM Desa dan juga pembuatan RKP Desa yang tidak melaui musyarah.

Tiga pendekatan terinstitusional dalam mengangkat kesejahteraan sosial (Midgley: 2005) yakni adalah kegiatan Pilantropi, Pekerjaan Sosial (bergantung pada tenaga professional), dan Pendekatan Administrasi Sosial atau pendekatan ini juga dikenal dengan layanan kesejahteraan sosial atau Pendekatan Kebijakan Sosial, (Midgley 2005).

Salah satu perwujudan kebijakan sosial yang digulirkan pemerintah adalah utperundang-undangan, pemerintah memiliki kewenangan membuat 


\section{Kebijakan Rencana Pembangunan Desa sebagai Usaha \\ Kesejahteraan Sosial Masyarakat di Desa Cidokom \\ - Enung Khoeriyah}

kebijakan publik yang mengatur pengusaha, lembaga pendidikan, perusahaan swasta agar mengadopsi ketetapan- ketetapan yang berdampak langsung pada kesejahteraan, (Suharto 2013).

Hadirnya Undang-Undang Desa nomor 6 tahun 2014 menjadi salah satu intervensi yang dilakukan pemerintah melalui kebijakan yang diambil dalam usaha pemerintah untuk meningkatkan kesejahteraan masyarakat desa. Undang-Undang nomor 6 tahun 2014 berisi tentang tatacara pemerintahan dan pembangunan desa dijalankan.

Dalam pembentukan Undang-Undang Desa nomor 6 tahun 2014 disebutkan bahwa desa memiliki hak asal-usul dan hak tradisional dalam mengatur dan mengurus kepentingan masyarakat setempat dan berperan mewujudkan cita-cita kemerdekaan berdasarkan Undang- Undang Dasar Negara Republik Indonesia tahun 1945, (UU Desa RI 2014).

Kesejahteraan sendiri diatur dalam Undang-Undang khusus sebagai kebijakan yang mengaturnya yakni, Undang-Undang Republik Indonesia nomor 11 tahun 2009 tentang Kesejahteraan Sosial.

Pasal 1 ayat 1 menyebutkan Kesejahteraan Sosial adalah:

"Terpenuhinya kebutuhan material, spiritual, dan sosial warga negara agar dapat hidup layak dan mampu mengembangkan diri, sehingga dapat melaksanakan fungsi sosialnya". (UU Desa RI 2014)

Sedangkan Midgley menjelaskan definisi kesejahteraan sebagai suatu keadaan yang:

"Suatu keadaan sejahtera secara sosial tersusun dari tiga unsur sebagai berikut. itu adalah pertama, setinggi apa masalah- masalah sosial dikendalikan, kedua seluas apa kebutuhan-kebutuhan dipenuhi, dan yang terakhir, setinggiapa kesempatan-kesempatan untuk maju tersedia. ketiga unsur ini berlaku bagi individu-individu, keluarga-keluarga, komunitaskomunitas dan seluruh masyarakat." (Rukminto Adi 2013)

Menurut gambaran di atas, konsep kesejahteraan berdasarkan UndangUndang dan juga konsep kesejahteraan yang diutarakan oleh Midgley adalah kesejahteraan merujuk pada kualitas kehidupan masyarakat yang lebih baik dan terpenuhinya kebutuhan secara sandang, pangan, papan maupun jaringan dalam hubungan masyarakat.

Sebagai wujud demokrasi untuk menjalankan otonominya di desa dibentuk Badan Permusyawarahan Desa (BPD) yang berfungsi sebagai lembaga legislatif dan pengawas terhadap pelaksanaan Peraturan Desa (Perdes), Anggaran Pendapatan dan Belanja Desa (APBD) serta keputusan kepala desa. 
Dalam arti sempit kepala desa dan pemerintahan desa berhak membuat kebijakan skala desa yang disesuaikan dengan kebutuhan desa tersebut.

Sedangkan kewenangan yang dimiliki desa dalam Undang- Undang nomor 6 tahun 2014 tentang desa pasal 18 yakni:

"Kewenangan desa meliputi kewenangan dibidang penyelenggaraan Pemerintahan Desa, Pelaksanaan Pembangunan Desa, Pembinaan Kemasyarakatan Desa, dan Pemberdayaan Masyarakat Desa Berdasarkan Prakarsa Masyarakat, Hak Asal Usul, Dan Adat Istiadat Desa." (UU Desa RI 2014).

Usaha yang dilakukan untuk mencapai kesejahteraan masyarakat desa salah satunya dilakukan melalui Perencanaan Pembangunan Desa. Pembangunan desa bertujuan meningkatkan desa dan kualitas hidup manusia serta penanggulangan kemiskinan melalui penyediaan pemenuhan kebutuhan dasar, pembangunan sarana dan prasarana, pengembangan potensi ekonomi lokal, serta pemanfaatan sumber daya alam dan lingkungan secara berkelanjutan.

Cidokom sebagai sebuah desa yang terbentuk atas aspirasi dari masyarakat, berupaya untuk terus meningkatkan kesejahteraan masyarakatnya melalui pembangunan desayang sebelumnya direncanakan melalui perencanaan seperti yang tercantum dalam pasal 79 Undang-Undang tentang Desa nomor 6 tahun 2014.

\section{Metodologi}

Dalam proses penelitian, peneliti menggunakan pendekatan penelitian kualitatif untuk kebutuhan riset dalam mengumpulkan dan menggunakan data. Menurut (Flick, 2002) penelitian kualitatif adalah keterkaitan spesifik pada studi hubungan sosial yang berhubungan dengan fakta dari pluralisasi dunia kehidupan (Gunawan 2013).

Dalam penelitian ini peneliti memfokuskan pada kebijakan perencanaan pembangunan melalui RPJMDesa dan juga pembuatan RKPDesa, tidak pada seluruh rangkaian musyawarah hal ini memungkinkan penulis untuk menggunakan metode pengumpulan data melalui purposive sampling dimana yang menjadi objek pengumpulan data hanya orang-orang tertentu yang memiliki pengetahuan atau informasi mengenai objek penelitian melalui observasi (RPJMDesa dan RKPDesa), wawancara (Kepala Desa, Ketua Urusan Pembangunan desa, Masyarakat Desa Ciokom), dan studi pustaka. 


\section{Kebijakan Rencana Pembangunan Desa sebagai Usaha \\ Kesejahteraan Sosial Masyarakat di Desa Cidokom \\ - Enung Khoeriyah}

\section{Hasil dan Diskusi}

"Desa" di Indonesia pertama kali ditemukan oleh Mr.Herman Warner Muntinghe, seorang Belanda anggota Raad Van Indie pada masa penjajahan colonial Inggris, yang merupakan pembantu Gubernur Jenderal Inggris yang berkuasa pada tahun 1811 di Indonesia. Dalam sebuah laporannya tertanggal 14 Juli 1817 kepada pemerintahnya disebutkan tentang adanya desa-desa di daerah-daerah pesisir utara pulau Jawa. Dan dikemudian hari ditemukan juga desa-desa di kepulauan luar Jawa yang kurang lebih sama dengan desa yang ada di Jawa (Soetarjo, 1984:36).

Undang-Undang nomor 6 tahun 2014 bab 1 pasal 1 tentang desa menerangkan bahwa:

"Desa adalah desa dan desa adatyang disebut dengan nama lain, selanjutnya disebut desa adalah kesatuan masyarakat hukum yang memiliki batas wilayah yang berwenang untuk mengatur dan mengurus urusan pemerintahan, kepentingan masyarakat setempat berdasarkan prakarsa masyarakat, hak asal-usul, dan atau hak tradisionalyang dihormati dalam sistem pemerintahan Negara Kesatuan Republik Indonesia." (UU Desa RI 2014).

Desa merupakan sebuah kesatuan masyarakat yang mampu mengatur dirinya sendiri berdasarakan hukum dan adat yang dimilikinya, desa memiliki kewenangan untuk mengatur kepentingan yang dimiliki masyarakatnya dengan menyesuaikan kondisi sosial yang ada di masyarakat, hal itu dapat disimpulkan bahwasanya desa telah memiliki otonomi dasar yang berasal dari identitas aslinya, berasal dari tradisi dan hukum yang dimilikinya bukan pemberian dari masyarakat luar ataupun pemerintah. Dalam lingkupnya Desa terdiri atas masyarakat desa dan juga pemerintah desa, dimana terdapat juga sumberdaya milik desa yang merupakan modal utama kesejahteraan masyarakat desa dalam merencanakan pembangunan

Untuk mencapai hal tersebut perlu adanya sebuah upaya atau usaha terencana yang dilakukan oleh pemerintah maupun masyarakat itu sendiri untuk menjadi sejahtera, hal itu bisa dilaksanakan melalui kegiatan usaha kesejahteraan sosial.

Peneliti melihat sebagai sebuah Desa yang sedang berada dalam tahap berkembang Cidokom terus berusaha untuk meningkatkan kualitas hidup masyarakatnyamelaluiberbagai pemenuhankebutuhan dasar terutama dibidang infrastruktur. Pembangunan terencana ini dijadikan alat oleh Pemerintah Desa 


\section{Kebijakan Rencana Pembangunan Desa sebagai Usaha \\ Kesejahteraan Sosial Masyarakat di Desa Cidokom}

Enung Khoeriyah

Cidokom untuk meningkatkan kesejahteraan masyarakatnya.

Hal ini sesuai dengan pengertian usaha kesejahteraan. Peneliti memahami usaha kesejahteraan sebagai segala bentuk usaha terencana yang dilakukan oleh individu atau kelompok, baik melalui aksi nyata atau pembuatan kebijakan dalam mencari jalan keluar atas permasalahan kesejahteraan yang mereka alami.

Kebijakan Undang-Undang Nomor 6 tahun 2014 tentang Desa, termasuk didalamnya mengatur tentang Rencana Pembangunan Desa serta tahapannya, yang disesuaikan dengan kebutuhan dan Priorotas program Desa.

Pemerintah desa menyusun perencanaan pembangunan Desa sesuai dengan kewenangan dengan mengacu pada perencanaan pembangunan Kabupaten/Kota. perencanaan dan pembangunan desa dilaksanakan oleh pemerintah dengan melibatkan seluruh masyarakat desa dengan semangat gotong royong. masyarakat desa berhak melakukan pemantauan terhadap pelaksanaan pembangunan desa (Kessa 2015).

Berdasarkan Undang-Undang No 6 Tahun 2014 tahapan pembangunan desa meliputi, tahapan perencanaan, tahapan pelaksanaan dan tahapan pengawasan (UU Desa RI 2014).

Perencanaan pembangunan Desa disusun secara berjangka meliputi: a) Rencana Pembangunan Jangka Menengah Desa(RPJMDes) untuk jangka waktu 6 (enam) tahun; dan b) Rencana Pembangunan Tahunan Desa atau yang disebut Rencana Kerja Pemerintah Desa (RKP DESA), merupakan penjabaran dari RPJM Desa untuk jangka waktu satu tahun.

\section{RPJM (Rencana Pembangunan Jangka Menengah) Desa}

RPJMDes atau Reancana Pembangunan Jangka Menengah Desa, ditetapkan dalam jangka waktu paling lama 3 (Tiga) bulan terhitung sejak pelantikan Kepala Desa. RKP Desa mulai disusun oleh pemerintah Desa pada bulan Juli tahun berjalan.

Di Desa Cidokom sendiri Rencana Pembangunan Jangka Menengah Desa dilakukan tiga bulan pertama setelah pelantikan, rencana pembangunan yang disusun adalah rencana pembangunan dan rencana kerja untuk 6 tahun kedepan atau selama kepala Desa menjabat selama satu periode.

Rencana Pembangunan Jangka Menengah Desa, disusun setelah dilakukan musyawarah desa yang diselenggarakan oleh Badan Permusyawarahan Desa 
dan Pemerintah Desa, dengan mengundang perwakilan masyarakat.

RancanganRPJMDesamemuatvisidanmisikepala desadanyangkemudian menjadi visi dan misi desa itu sendiri meliputi arah Kebijakan Pembangunan Desa, serta rencana kegiatan yang meliputi bidangpenyelenggraanpemerintahan desa, pelaksanaan pembangunan desa, pembinaan kemasyarakatan desa, dan pemberdayaan masyarakat desa. (Kessa 2015).

\section{Langkah-Langkah Penyusunan RPJM Desa}

Kepala desa dalam menyelenggarakan penyusunan RPJM Desa dengan mengikutsertakan seluruh unsur masyarakat desa dalam musyawarah desa. penyusunan Rencana Pembangunan Jangka Menengah (RPJM) Desa dilaksanakan dengan mempertimbangkan kondisi objektif desa dan prioritas program dan kegiatan kabupaten/ kota.

Setelah dalam musyawarah desa diketahui apa saja yang menjadi prioritas pembangunan maka disusun dalam penyusunan RPJM Desa, dilakukan dengan kegiatan yang meliputi:

\section{Pembentukan Tim Penyusun RPJM Desa}

Kepala Desa membentuk tim penyusun RPJM Desa, yang terdiri dari Kepala Desa selaku Pembina, Sekertaris Desa selaku ketua, Ketua lembaga pemberdayaan masyarakat selaku sekertaris; dan Anggota yang berasal dari perangkat Desa, Lembaga Pemberdayaan Masyarakat, kader pemberdayaan masyarakat Desa, dam unsur masyarakat lainnya, (Kessa 2015).

Tim penyusun RPJM Desa Cidokom adalah tim yang dibentuk sama dengan dalam menyusun RKP Desa atau Rencana Kerja Pemerintahan Desa yang teridri atas 11 orang yakni:

Tabel 1.1

Daftar Nama Tim Penyusun RPJM Desa

Tahun 2017 Desa Cidokom Kecamatan Gunungsindur

\begin{tabular}{clcll}
\hline No & \multicolumn{1}{c}{ Nama } & L/P & \multicolumn{1}{c}{ Jabatan/Pekerjaan } & \multicolumn{1}{c}{ Alamat } \\
\hline 1 & Sain Saputra, S.E & L & Kepala Desa/Pembina & Rt 005/003 \\
\hline 2 & Sabarudin & L & Sekertaris Desa/Ketua & Rt 004/004 \\
\hline 3 & Ujang Juheli & L & LPM/Sekertaris & Rt 004/004 \\
\hline 4 & Zulfahmi & L & Kaur/kasi Pembangunan & Rt 003/001 \\
\hline 5 & Andan Ipan & L & Ketua RW & Rt 003/005 \\
\hline 6 & Sarin & L & Tokoh Masyarakat & Rt 002/001 \\
\hline
\end{tabular}




\begin{tabular}{clcll}
\hline 7 & Supriyadi & L & Tokoh Pemuda & Rt 002/004 \\
\hline 8 & Marta Wijaya & L & Ketua RT & Rt 002/006 \\
\hline 9 & Suwadih & L & Tokoh Masyarakat & Rt 002/003 \\
\hline 10 & Misar Kurniawan & L & LPMD & Rt 001/002 \\
\hline 11 & Cunah Maryanag & P & Wakil Perempuan & Rt 002/002 \\
\hline
\end{tabular}

Sumber: RKP Desa Cidokom Tahun 2017

Tim penyusun RPJM Desa melakukan kegiatan-kegiatan, Pertama, Penyelarasan Arah Kebijakan Pembangunan Kabupaten/ Kota, kegiatan penyelarasan data desa dilakukan dengan memilih rencanakegiatankabupaten/ kota yang mungkin akan masuk dan sesuai dengan kondisi dan rencana pembangumam desa yang dikelompokan menjadi bidang penyelenggaraan pemerintah desa, pembangunan desa, pembinaan kemasyarakatan desa, dan pemberdayaan masyarakat desa. (Kessa 2015).

Tim perencanaan RPJMDesa akan melihat apa program prioritas yang mungkin akan dilakukan, Cidokom melihat evaluasi tahun sebelumnya sebagai salah satu refrensi dalam menentukan program Prioritas.

Kedua, Pengkajian Keadaan Desa, penyusun RPJM Desa melakukan pengkajian keadaan desa dalam rangka mempertimbangkan kondisi objektif desa. pengkajian keadaan desa, meliputi kegiatan: 1) Penyelarasan Data Desa: Dilakukan melalui pengambilan data dari dokumen desa dan membandingkannya dengan kondisi saat itu. penyelarasan data Desa Cidokom dilakukan dengan melihat arsip desa dan menerima langsung laporan kondisi masyarakat melalui Musdus atau Musyawarah dusun; 2) Penggalian Gagasan Masyarakat: Penggalian gagasan atau partisipasi masyarakat dilakukan secara partisipatif dengan melibatkan seluruh unsur masyarakat desa sebagai sumber data dan informasi. pelibatan masyarakat desa, dapat dilakukan melalui musyawarah dusun dan/atau musyawarah khusus unsur masyarakat seperti musyawarah RT/RW, (Kessa 2015); dan 3) Analisis Data dan Pelaporan: Tim penyusun RPJM Desa menyusun laporan hasil pengkajian keadaan Desa yang dituangkan dalam berita acara, yang dilampiri dokumen Data Desa yang sudah diselaraskan, Data Rencana program Pembangunan kabupaten/kota yang akan masuk ke Desa, Data Rencana Program Pembangunan Kawasan Per- Desaan; dan Rekapitulasi Usulan Rencana Kegiatan Pembangunan Desa Dari Dusun Dan/Atau Kelompok Masyarakat, (Kessa 2015). 


\section{Penyusunan Rencana Pembangunan Desa Melalui Musyawarah Desa}

Dalam musyawarah Desa hal-halyang menjadi pembahasan dan kemudian di sepakat: a) Laporan Hasil Pengkajian Desa; b) Rumusan Arah Kebijakan Pembangunan Desa Yang Dijabarkan Dari Visi Dan Misi Kepala Desa; dan c) Rencana Prioritas Kegiatan Penyelenggaraan Pemerintahan Desa, Pembangunan Desa, Pembinaan Kemasyarakatan Desa, Dan Pemberdayaan Masyarakat Desa.

Diskusi kelompok terarah tersebut membahas: a) Laporan hasil pengkajian keadaan Desa; b) Prioritas Rencana kegiatan Desa dalam jangka waktu 6 (enam) tahun; c) Sumber Rencana pembiayaan Rencana kegiatan Pembangunan Desa: dan d) Rencana pelaksanaan kegiatan Desa yang akan dilaksanakan oleh perangkat Desa, unsur masyarakat Desa, kerjasama antar Desa, dan/atau kerjasama Desa dengan pihak ketiga, (Kessa 2015).

\section{Penyusunan RPJM (Rencana Pembangunan JangkaMenengah) Desa}

Berdasarkan pertimbangan dan analisis yang dilakukan sebelumnya maka dilakukan Penyusunan Rencana Pembangunan Jangka Menengah Desa (RPJMDes) yang telah dilakukan oleh tim penyusun RPJM Desa sebagaimana dengan yang telah dipaparkan sebelumnya dibuatkan berita acara dan disampaikan kepada kepala Desa.

Kepala Desa memariksa Dokumen RPJM Desa yang telah dibuat sebelumnya dan jika perlu dilakukan perbaikan sesuai dengan arahan kepala Desa, jika telah disetujui maka langsung dilaksanakan.

Selain itu juga sebelum disahkan, Draft RPJMDesa terlebih dahulu diperiksa oleh Badan Permusyawarahan Desa yang memiliki tugas untuk pembuatan peraturan Desa, budgeting atau pengaturan pendanaan, dan Melakukan Fungsi Pengawa.

\section{Penyusunan Rencana Kerja Pemerintah (RKP) Desa}

Kepala Desa menyusun RKP Desa melalui musyawarah Desa, dilakukan dengan kegiatan: a) Penyusunan Perencanaan Pembangunan Desa melalui musyawarah: Badan permusyawarahan Desa (BPD) menyelenggarakan musyawarah antar staf Desa dengan masyarakat Desa dalam rangka Penyusunan Rencana Pembangunan Desa. Hasil musyawarah desa menjadi pedoman bagi pemerintah desa menyusun rancangan RKP (Rencana kerja pemerintah) Desa dandaftarusulanRKP Desa, musyawarah desa selambat-lambatnya dilaksanakan 
pada bulan juni tahun berjalan, (Kessa 2015); b) Pembentukan Tim penyusun RKP Desa: Kepala Desa membentuk tim penyusun RKP Desa terdiri dari 7 orang masing masing dari Kepala Desa selaku Pembina, Sekertaris Desa selaku ketua, Ketua lembaga pemberdayaan masyarakat, kader pemberdayaan masyarakat Desa, dan unsur masyarakat.

Tim penyusun Rencana kerja Pemerintah Desa Cidokom sama dengan tim penyusun RPJM Desayakni berjumlah 11 orangyang terdiri dari, Kepala Desa, Sekertaris Desa, LPM, Kasi Pembangunan, Satu Orang Ketua RW, Dua Orang Tokoh Masyarakat, Tokoh Pemuda, Ketua RT, LPMD dan satu orang perwakilan perempuan. (RKP Cidokom).

\section{Analisis Tahapan dan Implementasi Kebijakan Rencana \\ Pembangunan Desa sebagai Usaha Kesejahteraan Masyarakat Desa Cidokom}

Merujuk pada tahapan rencana pembangunan dan tahapan pembangunan desa yang telah dijelaskan, peneliti melihat Cidokom mengikuti alur yang dijelaskan dalam Undang-Undang: 1) Tahapan perencanaan yang meliputi Mustyawarah desa, pembuatan Peraturan Desa, pembuatan Rencana Pembangunan Desa, dan penyusunan Rencana Kerja Pemerintah Desa yang berisi penjabaran RPJM Desa; 2) Tahapan pembangunan, kegiatan ini merupakan implementasi dari perencanaan pembangunan yang telah disusun oleh masyarakatDesa, porses pembangunan melibatkan seluruh lapisan masyarakat melalui kegiatan gotong royong. Hal itu bertujuan untuk menanamkan rasa memiliki, sehingga masyarakat dapat menjaga hasil pembangunan dengan baik. Pada pelaksanaan pembangunan ini Pemerintah Desa menunjuk tim pelaksana kegiatan khusus yang bertugas untuk menjadi penanggung jawab lapangan pelaksanaan pembangunan Desa. 3) Tahapan Pengawasan, tahapan pengawasan kegiatan dilakukan oleh badan permusyawaratan desa atau BPD dari mulai perencanaan pembangunan, hingga pembangunan telah selesai. Pengawasan juga dilakukan oleh pihak ketiga, bahkan menurutberita onlineyang peneliti baca, Menteri sosial pernah meninjau secara langsung pembangunan yang dilakukan oleh Desa Cidokom

Dalam tahapan tersebut peneliti melihat bagaiman kerjasama yang baik dijalankan oleh pemerintah Desa Cidokom dalam usahanya untuk melakukan pembangunan desa, demi tercapainya sebuah tujuan pemerintah Desa 


\section{Kebijakan Rencana Pembangunan Desa sebagai Usaha \\ Kesejahteraan Sosial Masyarakat di Desa Cidokom \\ - Enung Khoeriyah}

bekerjasama dengan seluruh lapisan masyarakat untuk menjalankan amanat pembangunan guna mewujudkan masyarakat sejahtera.

\section{Analisis Implementasi Program Pembangunan Desa sebagai Usaha Meningkatkan Kesejahteraan Masyarakat Desa}

Tujuan Pembangunan Desa menurut UU nomor 6 Tahun 2014 meningkatkan kesejahteraan masyarakat, penanggulangan kemiskinan, pembangunan sarana dan prasarana Desa, pembangunan potensi ekonomi lokal, dan pemanfaatan sumberdaya alam dan lingkungan secara berkelanjutan.

Berikutnya peneliti tertarik untuk melihat sejauh mana masyarakatDesa Cidokommerasakan hasil daripembangunan, peneliti meminta pendapat sekitar beberapa orang masyarakat desa yang peneliti temui saat melakukan observasi ke desa terkait tanggapan mereka terhadap perencanaan pembangunan dan pelaksanaan pembangunan Desa Cidokom.

Peneliti melihat setelah perencanaan pembangunan hampir sebagian besar kegiatan pembangunan desa dapat terealisasikan, hal itu dapat dilihat pada tabel $1.1 \mathrm{di}$ atas terutama pembangunan akses jalan Desa.

Meskipun demikian peneliti melihat terdapat pembangunan yang sebelumnya tidak terencana pada Perencanaan Pembangunan Desa yakni Pembangunann Rumah Layak Huni (Rutilahu), jika merujuk pada keterangan kepala BPD diatas pembangunan Rutilahu tersebut diatur dalam Undang-Undang.

Pemerintah Desa Sendiri belum memiliki indikator jelas terkait bagaimana evaluasi perencanaan pembangunan dilakukan, hanya berdasarkan pada sejauh mana rencana pembangunan dapat terealisasi.

Berdasarkan penuturan dari kepala desa saat wawancara langsung dengan peneliti, masih ada beberapa realisasi pembangunan yang belum berjalan, hal ini dikarenakan keterbatasan lahan yang dimiliki oleh desa sehingga desa perlu menunggu untuk membeli atau menunggu donatur yang mau melepaskan tanahnya untuk digunakan untuk membangun Desa.

Namun demikian, pada hasilnya pembangunan yang dilakukan melalui perncanaan yang secara keseluruhannya melibatkan masyarakat desa dinilai baik oleh masyarakat desa dan diamini sebagai salah satu usaha untuk mensejahterakan masyarakatnya.

Hal ini terlihat dari saat dimana peneliti bertanya kepada warga yang ditemui tentang bagaimana makna sejahtera menurut mereka, secara garis besar 
mereka menyatakan bahwa sejahtera untuk mereka adalahmemilikibanyakuang dan materi lainnya, namun mereka merasa cukup bahagia dan sejahtera dengan kondisi mereka saat ini terutama karena Pemerintah Desa selalu berusaha untuk meningkatkan taraf hidup layak mereka melalui pembangunan.

Kebijakan Rencana Pembangunan Desa merupakan salah satu bentuk terencana usaha Pemerintah Pusat, Pemerintah Daerah, dan Desa yang ditujukan untuk meningkatkan kesejahteraan masyarakat yang dalam hal ini adalah masyarakat Desa yang dituangkan dalam Undang-Undang nomor 6 tahun 2014 .

Berdasarkan data penelitian diatas Kebijakan Perencanaan pembangunan Desa yang diamanatkan pemerintah dalam Undang- Undang Desa, menjadi pedoman penting bagi pemerintah desa untuk berupaya meningkatkan kesejahteraan masyarakatnya melalui pembangunan yang kemudian akan mengarah pada pembangunan sosial dan kesejateraan.

Dengan adanya undang-undang nomor 6 tahun 2014 pemerintah desa dan masyarakat lebih leluasa dalam merealisasikan pembangunan desa guna mencegah kesenjangan yang lebih tinggi antara pelayanan dan akses di desa dengan di kota, mengingat adanya perbedaan ketika desa diatur dalam undangundang nomor 6 tahun 2014 dengan undang-undang sebelumnya yakni undang-undang nomor 32 tahun 2004 tentang pemerintahan daerah dari segi pelaksanaan wewenang maupun kegiatan pembangunannya.

Sesuai dengan apa yang disampaikan oleh kepala desa Cidokom dengan adanya undang-undang desa dan dana desa saat ini desa lebih mudah dalam melaksanakan perencanaan pembangunan, karena tidak perlu menunggu instruksi dari daerah hanya cukup menyelesaikan laporan keuangan desa dan melaksanakan kewajiban desa, desa sudah bisa merencanakan program pembangunan.

\section{Kesimpulan}

Berdasarkan hasil penelitian yang dilakukan melalui observasi, studi dokumen, dan wawancara yang dilakukan peneliti mengenai Kebijakan Rencana Pembangunan Desa dalam usaha kesejahteraan sosialmasyarakat Desa Cidokom peneliti dapat mengambil kesimpulan sebagai berikut:

Pertama, Kebijakan Rencana Pembangunan Desa memuat tahapantahapan pembangunan yang secara keseluruhannya dibuat dengan melibatkan 


\section{Kebijakan Rencana Pembangunan Desa sebagai Usaha \\ Kesejahteraan Sosial Masyarakat di Desa Cidokom \\ - Enung Khoeriyah}

partisipasi masyarakat, dimulai dari Musyawarah Desa, Penyusunan Rencana Pembangunan Jangka Menengah Desa, Penyusunan Rencana Kerja Pemerintah Desa, Pembuatan Peraturan Desa dan Pengesahan RKPDesa. Dengan adanya Kebijakan Rencana Pembangunan Desa, melalui Undang-undang Desa nomor 6 tahun 2014 Perencanaan Pembangunan yang dibuat dinilai lebih teratur dan mudah untuk diterapkan.

Kedua, dalam implementasinya, Pembangunan Desa mengikuti tahapan pembangunan berdasarkan Kebijakan Undang-Undang yang meliputi, Tahapan Perencanaan, Tahapan Pelaksanaan, dan Tahapan Pengawasan. Ketiga tahapan ini melibatkan kerjasama antara Pemerintah Desa, Pemerintahan Desa dan juga Masyarakat pada umumnya. Sebagian besar Rencana pembangunan yang disusun dalam RKPDesa dapat direalisasikan dan disambut baik pula hasilnya oleh masyarakat, yang mana hal ini dilihat dari kuantitas program yang dilaksanakan, dan dibandingkan dengann perencanaan antar tahun kegiatan.

\section{Daftar Pustaka}

Kessa, Wahyudin. (2015). Perencanan Pembangunan Desa. Buku 6. Jakarta: Kementrian Desa, Pembangunan Daerah Tertinggal dan Transmigrasi Republik Indonesia.

Midgley, James. (2005). Pembangunan Sosial, Persfektif Pembangunan dalam Kesejahteraan Sosial. Jakarta: Direktorat Perguruan Tinggi Agama Islam, Departemen Agama RI.

Rukminto, Adi, Isbandi. (2013). Kesejahteraan Sosial (Pekerjaan Sosial, pembangunan Sosial dan Kajian Pembangunan.). 1 ed. Jakarta: PT Raja Grafindo Persada.

Suharto, Edi. (2013). Kebijakan Sosial Sebabagai Kebijakan Publik. Bandung: Alfabeta.

UU Desa RI, RI. 2014. “Undang-Undang Republik Indonesia nomor 6 Tahun 2014 Tentang Desa." http://www.dpr.go.id/dokjdih/document/uu/UU_2014_6. pdf.

Wasitiono, Sadu, dan Irwan Tahir. (2006). Prospek Pengembangan Desa. Bandung: CV. Fokus Media.

Rahardjo. (2010). Pengantar Sosiologi Pedesaan dan Pertanian. Yogyakarta: Gadjah Mada University Press. 